\title{
IMMOBILIZATION OF ELECTRIC ARC FURNACE DUST TOXIC ELEMENTS WITHIN THE MATRIX OF CONCRETE BASED PRODUCTS
}

\section{SIKALIDIS* \\ M. MITRAKAS \\ R. TSITOURIDOU}

Received: $17 / 02 / 10$

Accepted: 20/07/10

\author{
Aristotle University of Thessaloniki \\ Department of Chemical Engineering \\ 54124, Thessaloniki, Greece
}

*to whom all correspondence should be addressed: e-mail: sikalidi@auth.gr

\begin{abstract}
Electric Arc Furnace Dust (EAFD) generated through the production of carbon and alloy steel products is classified as environmentally hazardous waste mainly because of its relatively high levels of $\mathrm{Pb}, \mathrm{Cd}$ and $\mathrm{Cr}$. The aim of the present work was to investigate the effect of the EAFD addition on the properties of concrete building products (e.g concrete bricks) and to stabilize the toxic elements contained in EAFD in order to get environmentally accepted products. Concrete specimens were prepared by vibration and press-forming of mixtures containing cement, sand, dolomite, calcium stearate with water and the addition of different percentages of EAFD. For the immobilization of the toxic elements of EAFD within the matrix of the specimens, different percentages of each one of $\mathrm{NaH}_{2} \mathrm{PO}_{4}, \mathrm{H}_{3} \mathrm{PO}_{4}$ and of a mixture of $\mathrm{H}_{3} \mathrm{PO}_{4}$ - $\mathrm{FeSO}_{4} \cdot 7 \mathrm{H}_{2} \mathrm{O}$ were added successively to each one of the mixtures as stabilizing materials. Modulus of rupture (MOR) and water absorption (WA) tests showed that the specimens produced had specifications within accepted limits for relevant products. Leaching tests applied on the specimens proved the compliance with imposed leachate Maximum Acceptable Limits (MAL), since the practiced stabilizing materials effectively immobilize toxic elements within the prepared specimens.
\end{abstract}

KEYWORDS: EAFD; Concrete products; Metals immobilization; Stabilization; Leaching; Phosphates; Ferrous salts.

\section{INTRODUCTION}

The EAFD production is increasing proportionally to the increase of steel production by Electric Arc Furnace (EAF) process. The specific dust portion per ton of crude steel in the electric steel process is about 10 to 15 kilos or approximately $1.5 \%$ of the scrap steel charged to the EAF (Menad et al., 2003; Mager et al., 2000). The average range of Electric Arc Furnace Dust (EAFD) is about $10 \mathrm{~kg}$ per ton of steel melt. The worldwide output of EAFD exceeded the $3.7 \times 10^{6} \mathrm{tn} /$ year as was forecasted (Mager et al.; 2000). The EAFD produced annually in Greece from the five plants producing steel by EAF process was estimated to be approximately $3 \times 10^{4}$ tons (Sidenor, 2008).

EAFD is classified as an environmentally hazardous waste in most regions of the world, mainly because of its relatively high levels of $\mathrm{Pb}, \mathrm{Cr}, \mathrm{Cd}$ and halides and in general because of its chemical and physical properties (Mitrakas et al.,2007; Cheng, 2003; Mager et al., 2000). Among other parameters (Sikalidis et al., 2006; Franco et al., 2005) air pollution by EAFD particulates was reported to be connected to cancer (Adamson et al., 2000; Valavanidis et al., 2008). The chemical composition of EAFD depends on the quality of steel scrap processed, the type of steel being produced, the technological and operating conditions and the degree of dust recycling into process (Rocabois et al., 2000; Delalio et al., 2000; Sofilic et al., 2004).

Most of the so far developed and commercialized processes are predominantly applied to the recovery of heavy metals from the EAFD, the re-cycling of EAFD and to a lesser extent to its inactivation prior to permanent disposal to landfills (Zunkel and Schmitt, 1995).

Currently, about $55 \%$ of EAFD is processed by high temperature metal recovery processes, mainly for $\mathrm{Zn}$ and $\mathrm{Pb}$ recovery. Although these methods and also the hydrometallurgical ones have high cost, are used because of the limited number of approved process alternatives for treating these hazardous 
wastes. Although developed and emerging technologies are available to stabilize EAFD for burial in landfills, the long term interest of industry and state will be better served by technologies that are utilizing EAFD in a way to result to profitable economics. Alternative processes have been developed to produce industrial products by using EAFD. Pisciella et al. (2001) used EAFD together with other industrial wastes to produce glasses. Sikalidis and Mitrakas (2006) completely stabilize EAFD within a sintered ceramic body and developed environmentally accepted ceramic products which resulted to profitable economics.

Almost all the rest $45 \%$ of the EAFD is disposed in landfills. EAFD must be stabilized for safe disposal in accordance to the environmental regulations, since it has been designed by the USEPA as a hazardous waste (K061). Many treatments have been applied for EAFD stabilization. Pereira et al. (2001) used coal fly ash as the fundamental raw material and main binder in EAFD solidification/stabilization process. The concentration of metals in leachate from the solidification/stabilization products was a strongly $\mathrm{pH}$ dependent; thus, the final $\mathrm{pH}$ of the leachate is the most important variable in reaching the imposed limits and therefore in meeting the stabilization goals. To assure that the $\mathrm{Pb}, \mathrm{Zn}, \mathrm{Cr}$ and $\mathrm{Cd}$ concentration limits are not exceeded in leachates, the final $\mathrm{pH}$ of the leachate must be within a range of values corresponding to the minimum solubility of the metals in the leaching medium. This is normally achieved in the $\mathrm{pH}$ range 8.011.3 for TCLP leachates and in the pH range 9.4-10.3 for DIN leachates. However, toxic wastes' leachate must fulfill the Maximum Acceptable Limits (MAL) for landfill disposal, which has already set for certain chemical parameters by the European Community (2003). In an attempt to reduce metals leachability of EAFD various acidic materials as immobilization materials were investigated (Mitrakas et al., 2007). Among them $\mathrm{H}_{3} \mathrm{PO}_{4}$ proved the most effective one, since the concentration in leachate of all EAFD metals, especially that of $\mathrm{Pb}$, was found almost two order lower than MAL in a wide range of $\mathrm{pH}(7-11.5)$.

The aim of the present work was to convert the toxic industrial waste EAFD, to a useful raw material for the production of environmentally accepted concrete building products by stabilizing the toxic elements that contains using phosphate acidic materials.

\section{MATERIALS AND METHODS}

\subsection{Samples Preparation}

Concrete based brick specimens were prepared by vibration and press-forming of mixtures containing cement, river sand and crushed dolomite with water and the addition of different percentages of EAFD and $\mathrm{NaH}_{2} \mathrm{PO}_{4}, \mathrm{H}_{3} \mathrm{PO}_{4}$ and a mixture of $\mathrm{H}_{3} \mathrm{PO}_{4}$ and $\mathrm{FeSO}_{4} .7 \mathrm{H}_{2} \mathrm{O}$ as acidic materials for heavy metals immobilization. The formula of the mixture, the preparation parameters and the groups of specimens prepared are given in the Table 1.

Table 1. Formula of the mixture and preparation parameters for the concrete based brick specimens

\begin{tabular}{|c|c|}
\hline Formula of the mixtures & Preparation parameters \\
\hline River sand (0 -2 mm) & Water to cement ratio \\
\hline Dolomite $(0-1 \mathrm{~mm})$ & Frequency of vibration $3000 \mathrm{sc} \mathrm{min}^{-1}$ \\
\hline Cement I $42.5 \mathrm{~N}$ & Amplitude of vibration \\
\hline Calcium stearate $66 \mathrm{~g} / 100 \mathrm{~kg}$ of the batch & Pressure applied \\
\hline $\begin{array}{l}\text { EAFD }^{1} \quad 0,5,10 \text { and } 15 \% \mathrm{w} / \mathrm{w} \\
\text { (in substitution of the sand) }\end{array}$ & $\begin{array}{l}\text { Size of the specimens, } \mathrm{cm} \\
16 \times 4 \times 4,10 \times 10 \times 3\end{array}$ \\
\hline \multicolumn{2}{|c|}{$\begin{array}{l}1^{\text {st }} \text { Group of specimens } \\
\mathrm{NaH}_{2} \mathrm{PO}_{4}, 1,2,3 \% \mathrm{w} / \mathrm{w} \text { in addition in specimens containing } 0,5,10,15 \% \mathrm{w} / \mathrm{w} \text { EAFD } \\
2^{\text {nd }} \text { Group of specimens } \\
\mathrm{H}_{3} \mathrm{PO}_{4} 1,2,3 \% \mathrm{w} / \mathrm{w} \text { in addition in specimens containing } 0,5,10,15 \% \mathrm{w} / \mathrm{w} \text { EAFD } \\
3^{\mathrm{d}} \mathrm{Group} \text { of specimens } \\
\mathrm{H}_{3} \mathrm{PO}_{4} 1 \% \mathrm{w} / \mathrm{w}+\mathrm{FeSO}_{4} \cdot 7 \mathrm{H}_{2} \mathrm{O} 0.25 \% \mathrm{w} / \mathrm{w}, \\
\text { in addition in specimens containing } 0,5,10,15 \% \mathrm{w} / \mathrm{w} \text { EAFD }\end{array}$} \\
\hline
\end{tabular}

\subsection{Methods of Analyses and Testing}

The concentrations of the metals in the EAFD as well as in the specimens' leachates were determined by using a Perkin Elmer AAnalyst 800 atomic absorption spectrophotometer either with flame or graphite furnace. Carbonate and hydroxide content of leachates were determined by titration according to Standard Methods 2320 B. (Alpha AWWA WEF, 1992). Leaching tests on EAFD and specimens were performed in 
compliance to EN 12457.1 (2002) and EN 12457.4 (2002) according to the particle size of the material. The method followed for the study of influence of $\mathrm{pH}$ on leachability is described by Mitrakas et al., (2007). The testing methods and the accepted values for Modulus of rupture (MOR) and water absorption for the prepared products are given by Sikalidis and Mitrakas (2006).

\section{RESULTS AND DISCUSSION}

3.1. Chemical and technical characteristics.

The $\mathrm{Pb}$ concentrations in the EAFD leachate (Table 2) were found to be far above the MAL (EN 12457, 2002) suggesting the necessity of measures to be taken in order to be disposed in landfills.

In addition, the experimental results of Table 2 show that significant quantity of $\mathrm{Cr}(\mathrm{VI})$ was leached from cement, which contribute to the total chromium leached from the concrete based specimens. In order to stabilize the leached $\mathrm{Pb}$, the EAFD was incorporated in concrete building products.

Table 2. Chemical characteristics of EAFD, its leachate* and of cement leachate**

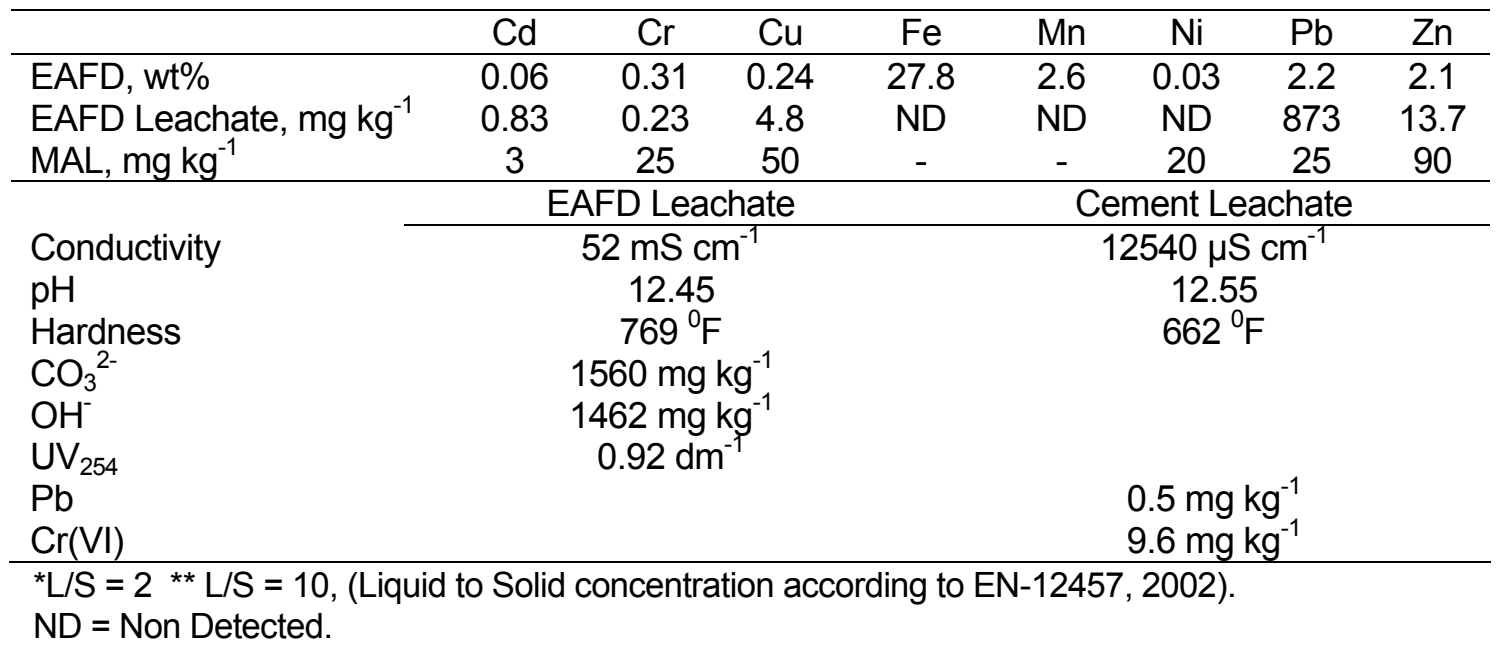

Table 3. MOR ${ }^{*}$ and WA of the concrete based specimens prepared by the addition of EAFD and of successive over and above addition of each one of $\mathrm{NaH}_{2} \mathrm{PO}_{4}$, of $\mathrm{H}_{3} \mathrm{PO}_{4}$ and of $\mathrm{H}_{3} \mathrm{PO}_{4}$ plus $\mathrm{FeSO}_{4} .7 \mathrm{H}_{2} \mathrm{O}$

\begin{tabular}{|c|c|c|c|c|c|c|c|c|c|}
\hline EAFD & \multicolumn{3}{|c|}{$\mathrm{NaH}_{2} \mathrm{PO}_{4}$} & \multicolumn{3}{|c|}{$\mathrm{H}_{3} \mathrm{PO}_{4}$} & \multicolumn{3}{|c|}{ 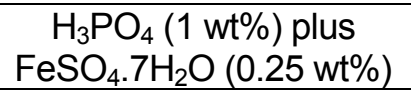 } \\
\hline wt $\%$ & wt $\%$ & 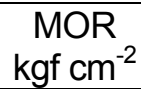 & $\begin{array}{l}\text { WA } \\
\text { wt } \%\end{array}$ & wt $\%$ & $\begin{array}{c}\text { MOR } \\
\text { kgf } \mathrm{cm}^{-2}\end{array}$ & $\begin{array}{l}\text { WA } \\
\text { wt } \%\end{array}$ & $w t \%$ & $\begin{array}{c}\text { MOR } \\
\text { kgf } \mathrm{cm}^{-2}\end{array}$ & $\begin{array}{l}\text { WA } \\
\text { wt } \%\end{array}$ \\
\hline 0 & 0 & 43 & 7.6 & 0 & 43 & 7.6 & 0 & 43 & 7.6 \\
\hline 5 & 0 & 44 & 7.6 & & & & & & \\
\hline ॥ & 1 & 43 & 8.1 & 1 & 41 & 3.7 & 1.25 & 36 & 4.2 \\
\hline » & 2 & 42 & 8.3 & & & & & & \\
\hline » & 3 & 42 & 8.6 & & & & & & \\
\hline 10 & 0 & 48 & 7.8 & & & & & & \\
\hline » & 1 & 36 & 8.4 & 1 & 36 & 3.9 & 1.25 & 31 & 4.5 \\
\hline$»$ & 2 & 35 & 8.5 & & & & & & \\
\hline » & 3 & 33 & 9.7 & & & & & & \\
\hline 15 & 0 & 46 & 7.6 & & & & & & \\
\hline " & 1 & 30 & 8.6 & 1 & 30 & 4.4 & 1.25 & 26 & 4.7 \\
\hline " & 2 & 28 & 9.0 & & & & & & \\
\hline ॥ & 3 & 20 & 9.3 & & & & & & \\
\hline
\end{tabular}

${ }^{*} \mathrm{MOR}$ tests were performed 27 days after the specimens' preparation day

MOR and WA were tested since these properties are essential for the specimens' technical characterization. They were measured according to EU standard methods of testing of EN 772-01 (2000). The addition of EAFD found to have a positive effect on MOR values being in agreement to Sikalidis and Mitrakas (2006). The addition of stabilizing materials found to have a noticeable negative effect 
especially in the case of higher EAFD concentrations (Table 3). The presence of these materials might affect negatively the formation of other compounds that assist setting and strength, which needs further investigation. Low WA values observed in the case of $\mathrm{H}_{3} \mathrm{PO}_{4}$ and of $\mathrm{H}_{3} \mathrm{PO}_{4} / \mathrm{FeSO}_{4} .7 \mathrm{H}_{2} \mathrm{O}$, were connected to relatively higher MOR values compared to $\mathrm{NaH}_{2} \mathrm{PO}_{4}$ addition. This also could be attributed to the effect of stabilizing materials on the formation of various compounds during setting, which needs also further investigation. Concerning the MOR and WA values, from the added stabilizing materials, the a) $1 \mathrm{wt} \% \mathrm{NaH}_{2} \mathrm{PO}_{4}$, b) $1 \mathrm{wt} \% \mathrm{H}_{3} \mathrm{PO}_{4}$ and c) $1.25 \mathrm{wt} \%\left[\mathrm{H}_{3} \mathrm{PO}_{4}(1 \mathrm{wt} \%)\right.$ plusFeSO $\left.\mathrm{S}_{4} .7 \mathrm{H}_{2} \mathrm{O}(0.25 \mathrm{wt} \%)\right]$ additions over and above the $5 \mathrm{wt} \%$ EAFD appears to be the most promising (Table 3 ). The MOR and WA values could be improved by more intense vibration of the moulds and relatively higher powder pressing.

\subsection{Leaching tests}

The European Counsel Directive 33/16-1-2003, is establishing MAL for the elements under consideration for disposal of the wastes in landfills. The addition of EAFD alone in concrete-based specimens might result to products which are close to the limit in order to be characterized as environmentally accepted. The quantities leached in $\mathrm{mg} \mathrm{kg}^{-1}$ according to the EU directive 33 (2003), for the most of the chemical parameters are lower from the accepted limits i.e.: As $<0.02, \mathrm{Ba}<1, \mathrm{Cd}<0.002, \mathrm{Cu}<0.2, \mathrm{Fe}<0.5, \mathrm{Hg}<0.002, \mathrm{Mn}<0.2, \mathrm{Ni}<0.2$, $\mathrm{Sb}<0.02, \mathrm{Sn}<0.2, \mathrm{~F}^{-} 1-3, \mathrm{Cl}^{-} 2-4 \times 10^{3}, \mathrm{PO}_{4}{ }^{3-} 0.2-0.6$. This low leachability of the toxic parameters could be attributed in both; the fixation of the wastes particles in the concrete solid matrix and the immobilization due to chemical binding of the elements.

However, EAFD addition of 10 and $15 \mathrm{wt} \%$ resulted in leached Pb quantities 5.1 and $5.5 \mathrm{mg} \mathrm{kg}^{-1}$ (Table 4), respectively, over passing the MAL $\left(5 \mathrm{mg} \mathrm{kg}^{-1}\right)$ for non dangerous wastes disposal.

Table 4. Influence of $\mathrm{NaH}_{2} \mathrm{PO}_{4}, \mathrm{H}_{3} \mathrm{PO}_{4}$ and of $\mathrm{H}_{3} \mathrm{PO}_{4} / \mathrm{FeSO}_{4} .7 \mathrm{H}_{2} \mathrm{O}$ additions on $\mathrm{Pb}$ and $\mathrm{Cr}(\mathrm{VI})$ leachability from concrete based specimens prepared by EAFD addition

\begin{tabular}{|c|c|c|c|c|c|c|c|c|c|}
\hline \multirow{3}{*}{$\begin{array}{c}\text { EAFD } \\
w t \%\end{array}$} & \multirow[b]{2}{*}{$\mathrm{NaH}_{2} \mathrm{PO}_{4}$} & \multicolumn{2}{|c|}{ Leachate } & \multicolumn{3}{|c|}{ Leachate } & \multirow{3}{*}{$\begin{array}{l}1 \mathrm{wt} \% \mathrm{H}_{3} \mathrm{PO}_{4} \\
\text { plus } 0.25 \mathrm{wt} \% \\
\mathrm{FeSO}_{4} .7 \mathrm{H}_{2} \mathrm{O}\end{array}$} & \multicolumn{2}{|c|}{ Leachate } \\
\hline & & $\mathrm{Pb}$ & $\mathrm{Cr}(\mathrm{VI})$ & $\mathrm{H}_{3} \mathrm{PO}$ & $\mathrm{Pb}$ & $\mathrm{Cr}(\mathrm{VI})$ & & & $\mathrm{Cr}(\mathrm{VI})$ \\
\hline & $w t \%$ & \multicolumn{2}{|c|}{$\mathrm{mg} \mathrm{kg}^{-1}$} & wt $\%$ & \multicolumn{2}{|c|}{$\mathrm{mg} \mathrm{kg}^{-1}$} & & \multicolumn{2}{|c|}{$\mathrm{mg} \mathrm{kg}^{-1}$} \\
\hline 5 & 0 & 1.0 & 2.7 & & 1.0 & 2.7 & & 1.0 & 2.7 \\
\hline$»$ & 1 & 0.8 & 2.7 & 1 & 0.8 & 0.6 & 1.25 & 0.7 & 0.4 \\
\hline$»$ & 2 & 0.5 & 4.3 & & & & & & \\
\hline$»$ & 3 & 0.2 & 6.4 & & & & & & \\
\hline 10 & 0 & 5.1 & 4.0 & & & & & & \\
\hline$»$ & 1 & 1.8 & 4.1 & 1 & 2.3 & 1.4 & 1.25 & 2.3 & 0.5 \\
\hline$»$ & 2 & 1.5 & 5.4 & & & & & & \\
\hline$»$ & 3 & 1.4 & 7.2 & & & & & & \\
\hline 15 & 0 & 5.5 & 4.3 & & & & & & \\
\hline$»$ & 1 & 2.6 & 5.1 & 1 & 4.3 & 1.5 & 1.25 & 3.3 & 0.8 \\
\hline 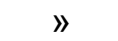 & 2 & 2.2 & 6.3 & & & & & & \\
\hline$»$ & 3 & 2.0 & 8.4 & & & & & & \\
\hline \multicolumn{10}{|c|}{$\begin{array}{c}\text { MAL in } \mathrm{mg} \mathrm{kg}^{-1} \text { (Liquid/Solid ratio, } \mathrm{L} / \mathrm{S}=2 \text { ) for } \mathrm{Pb} \text { and } \mathrm{Zn} \text { for inert, non dangerous and dangerous } \\
\text { wastes for landfill disposal }(\mathrm{EN} 12457-1,2002)\end{array}$} \\
\hline & \multicolumn{3}{|c|}{ Inert wastes } & \multicolumn{3}{|c|}{ Non Dangerous } & \multicolumn{3}{|c|}{ rous wastes } \\
\hline $\mathrm{Pb}$ & \multicolumn{3}{|c|}{0.2} & \multirow{2}{*}{\multicolumn{3}{|c|}{5}} & \multirow{2}{*}{\multicolumn{3}{|c|}{25}} \\
\hline $\mathrm{Cr}$ & \multicolumn{3}{|c|}{0.2} & & & & & & \\
\hline
\end{tabular}

This high leachability of $\mathrm{Pb}$ could be attributed to high $\mathrm{pH}$ value of the leachate (Table 5), since from $\mathrm{pH} 12$ to $13, \mathrm{~Pb}$ appears in the extremely soluble form $\mathrm{Pb}(\mathrm{OH})_{4}^{2-}$ according to the reaction 1 :

$\mathrm{Pb}^{2+}+4 \mathrm{H}_{2} \mathrm{O} \leftrightarrow \mathrm{Pb}(\mathrm{OH})_{4}{ }^{2-}+4 \mathrm{H}^{+} \quad$ logK= -39.699

Leaching tests performed on concrete-based specimens containing various percentages of EAFD $(5,10$, $15 \%$ ) showed that after the additions of even $1 \%$ of $\mathrm{NaH}_{2} \mathrm{PO}_{4}$ or $\mathrm{H}_{3} \mathrm{PO}_{4}$ or of $\mathrm{H}_{3} \mathrm{PO}_{4} / \mathrm{FeSO}_{4} .7 \mathrm{H}_{2} \mathrm{O}$ mixture, the $\mathrm{Pb}$ concentrations in the leachate decreases significantly below MAL for landfill disposal of nondangerous materials (Table 4). This low $\mathrm{Pb}$ solubility could be attributed to the formation of pyromorphite type minerals (Yang et al., 2001) favored from the presence of relatively high $\mathrm{Cl}^{-}\left(2-4 \mathrm{~g} \mathrm{~kg}^{-1}\right)$ concentration (reaction 2). These results are in agreement with previous work of Mitrakas et al., (2007).

$5 \mathrm{~Pb}^{2+}+3 \mathrm{H}_{2} \mathrm{PO}_{4}^{-}+\mathrm{Cl}^{-} \leftrightarrow \quad \mathrm{Pb}_{5}\left(\mathrm{PO}_{4}\right)_{3} \mathrm{Cl}_{(\mathrm{s})}+6 \mathrm{H}^{+} \quad$ logK $=-25.05$ 
The relatively high quantities, in comparison to above mentioned metals, of $\mathrm{Cr}$ in $\mathrm{Cr}(\mathrm{VI})$ form that leached from concrete-based specimens was attributed to cement (Table 4), since no $\mathrm{Cr}(\mathrm{VI})$ detected in EAFD leachates. However, the quantity of $\mathrm{Cr}(\mathrm{VI})$ was increased as the addition of $\mathrm{NaH}_{2} \mathrm{PO}_{4}$ increased (Table 4 ), either due to the increase of hydroxyl concentration, or probably due to the higher amount -as expressed by the conductivity - of soluble salts leached (Table 5).

Addition of $\mathrm{NaH}_{2} \mathrm{PO}_{4}$ results in precipitation of metals in the most insoluble form of phosphate salts instead of hydroxides increasing hydroxyl and other soluble ions (e.g. chromate) concentration and in the leachate. For this reason the experiments with additions of $\mathrm{H}_{3} \mathrm{PO}_{4}$ and of $\mathrm{H}_{3} \mathrm{PO}_{4} / \mathrm{FeSO}_{4} .7 \mathrm{H}_{2} \mathrm{O}$ mixture were performed. These additions were successfully reduced the concentration of $\mathrm{Cr}(\mathrm{VI})$ in the leachate below the MAL (Table 4). Experimental data of Table 4 showed also significant influence of $\mathrm{Fe}^{2+}$ to $\mathrm{Cr}(\mathrm{VI})$ leached, due to $\mathrm{Cr}(\mathrm{VI})$ reduction to most insoluble form of $\mathrm{Cr}(\mathrm{III})$ hydroxide.

Table 5. Influence of $\mathrm{NaH}_{2} \mathrm{PO}_{4}, \mathrm{H}_{3} \mathrm{PO}_{4}$ and of $\mathrm{H}_{3} \mathrm{PO}_{4} / \mathrm{FeSO}_{4} .7 \mathrm{H}_{2} \mathrm{O}$ additions on the leaching characteristics of concrete based specimens prepared by EAFD addition

\begin{tabular}{|c|c|c|c|c|c|c|}
\hline $\begin{array}{l}\text { EAFD } \\
(w t \%)\end{array}$ & $\begin{array}{c}\mathrm{NaH}_{2} \mathrm{PO}_{4} \\
\text { (wt\%) }\end{array}$ & $\mathrm{pH}$ & $\begin{array}{l}\text { Conductivity } \\
\left(\mathrm{mS} \mathrm{cm}^{-1}\right)\end{array}$ & $\begin{array}{c}\text { Hardness } \\
\left({ }^{0} \mathrm{~F}\right)\end{array}$ & $\begin{array}{c}\mathrm{OH}^{-} \\
\left(\mathrm{mg} \mathrm{kg}^{-1}\right)\end{array}$ & $\begin{array}{c}\mathrm{CO}_{3}{ }^{2-} \\
\left(\mathrm{mg} \mathrm{kg}^{-1}\right)\end{array}$ \\
\hline 0 & 0 & 12.45 & 7.5 & 573 & 2,217 & 192 \\
\hline 5 & 0 & 11.85 & 7.5 & 610 & 1,496 & 288 \\
\hline$»$ & 1 & 12.00 & 10.5 & 274 & 2,462 & 240 \\
\hline$»$ & 2 & 12.00 & 12.9 & 285 & 2,829 & 288 \\
\hline 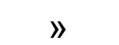 & 3 & 12.00 & 15.9 & 291 & 2,843 & 480 \\
\hline 10 & 0 & 11.75 & 10.4 & 587 & 1,333 & 240 \\
\hline$»$ & 1 & 11.85 & 11.5 & 276 & 2,189 & 240 \\
\hline$»$ & 2 & 12.00 & 14.8 & 287 & 2,842 & 240 \\
\hline$»$ & 3 & 12.10 & 21.3 & 302 & 3,305 & 336 \\
\hline 15 & 0 & 11.70 & 10.5 & 613 & 1,210 & 144 \\
\hline 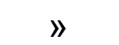 & 1 & 11.85 & 12.6 & 347 & 1,700 & 192 \\
\hline$»$ & 2 & 12.15 & 17.4 & 353 & 2,955 & 238 \\
\hline$»$ & 3 & 12.15 & 17.5 & 385 & 2,992 & 240 \\
\hline 0 & $1 \% \mathrm{H}_{3} \mathrm{PO}_{4}$ & 12.45 & 7.5 & 573 & 2,217 & 192 \\
\hline 5 & $>$ & 11.95 & 8.4 & 693 & 999 & 96 \\
\hline 10 & $\gg$ & 12.05 & 10.1 & 740 & 1,020 & 96 \\
\hline 15 & $>$ & 12.05 & 13.5 & 756 & 1,129 & 120 \\
\hline & $1 \mathrm{wt} \% \mathrm{H}_{3} \mathrm{PO}_{4}$ plus & & & & & \\
\hline 0 & $0.25 \mathrm{wt} \% \mathrm{FeSO}_{4} 7 \mathrm{H}_{2} \mathrm{O}$ & 12.45 & 7.5 & 573 & 2,217 & 192 \\
\hline 5 & >> & 12 & 8.7 & 724 & 755 & 120 \\
\hline 10 & $\gg$ & 12 & 10.3 & 740 & 939 & 120 \\
\hline 15 & $>$ & 12.05 & 12.5 & 771 & 755 & 120 \\
\hline
\end{tabular}

\section{CONCLUSIONS}

The main problem for the environmental disposal of the EAFD is the high leachability of the various toxic metals that contains and mainly of $\mathrm{Pb}$. Technological tests support the utilization of EAFD as raw material in the production of concrete-based building products like bricks, tiles etc, if the $\mathrm{Pb}$ leachability problem could be solved. The $\mathrm{Pb}$ stabilization within the structure of these products was achieved with the addition of small percentages of each one $\mathrm{NaH}_{2} \mathrm{PO}_{4}, \mathrm{H}_{3} \mathrm{PO}_{4}$ and $\mathrm{H}_{3} \mathrm{PO}_{4} / \mathrm{FeSO}_{4} .7 \mathrm{H}_{2} \mathrm{O}$ mixture. Furthermore $\mathrm{H}_{3} \mathrm{PO}_{4}$ and $\mathrm{H}_{3} \mathrm{PO}_{4} / \mathrm{FeSO}_{4} .7 \mathrm{H}_{2} \mathrm{O}$ mixture additions were successfully reduced both, the concentration of $\mathrm{Cr}(\mathrm{VI})$ and of $\mathrm{Pb}$ in the leachate, significantly below the MAL for non dangerous wastes for landfill disposal. The products obtained found to be technically and environmentally accepted, resulting also to profitable economics.

\section{REFERENCES}

Adamson I.Y.R., Prieditis H., Hedgecock C., Vincent R. (2000), Zinc is the toxic factor in the lung response to an atmospheric particulate sample, Toxicol. Appl. Pharmacol, 166, 111-119.

Cheng T.W. (2003), Combined glassification of EAF dust and incinerator fly ash, Chemosphere, 50, 47-51.

Delalio A., Bajger Z., Balaz P., Castro F. (2000), Characterization and pretreatment of steelmaking dusts in order to recover valuable products. In: Massacci, P., Ed.; Proceedings of the XXIth International Mineral Processing Congress 2000, Sec. C12-a, University of Rome La Sapienza, Italy, pp. 15-19. 
European Council Directive 33/16-01-2003, Council Decision of 19 December 2002 establishing criteria and procedures for the acceptance of waste at landfills pursuant to Article 16 of and Annex II to Directive 1999/31/EC.

European Standard EN 12457-1 (2002), Characterisation of waste - Leaching - Compliance test for leaching of granular waste materials and sludges - Part 1: One stage batch test at a liquid to solid ratio of $2 \mathrm{~L} / \mathrm{kg}$ for materials with high solid content and with particle size below $4 \mathrm{~mm}$ (without or with size reduction).

European Standard EN 12457-4 (2002), Characterisation of waste - Leaching - Compliance test for leaching of granular waste materials and sludges - Part 1: One stage batch test at a liquid to solid ratio of $10 \mathrm{~L} / \mathrm{kg}$ for materials with high solid content and with particle size below $10 \mathrm{~mm}$ (without or with size reduction).

European Standard Methods of Test for masonry units (2000), Determination of: Compressive and flexural Strength of mortars EN 772-01, Water Absorption EN 772-11.

Franco A., Sikalidis A.K., Herruzo J.A.S. (2005), Colorectal cancer: influence of diet and lifestyle factors, Revista Espanola de Enfermedades Digestivas, 97(6), 432-441.

Mager K., Meurer U., Garcia-Egocheaga B., Goicoechea N., Rutten J., Saage W., Simonetti F. (2000), Recovery of zinc oxide from secondary raw materials: New Developments of the Waeltz Process. In: $4^{\text {th }}$ international symposium on recycling of metals and engineering materials, Stewart D.L., Stephens R., Daley J.C. (Eds), The Minerals, Metals \& Materials Society 2000, 329-344.

Menad N., Ayala J.N., Garcia-Carcedo F., Ruiz-Ayúcar E., Hernández A. (2003), Study of the presence of fluorine in the recycled fractions during carbothermal traetment of EAF dust. Waste Management, 23, 483-491.

Mitrakas M., Sikalidis C. and Karamanli Th. (2007), Immobilization of EAFD heavy metals using acidic materials, Journal of Environmental Science and Health Part A, 42, 535-541.

Pereira F., Rodríguez-Piñero M., Vale J. (2001), Solidification/stabilization of electric arc furnace dust using coal fly ash. Analysis of the stabilization process, J. Hazardous Materials, B82, 183-195.

Pisciella P., Crisucci S., Karamanov A., Pelino M. (2001), Chemical durability of glasses obtained by vitrification of industrial wastes, Waste Management, 21, 1-9.

Rocabois P., Huber J.C., Lectard E., Ptisson F. (2000), Thermodynamic assesment of the oxide phase in the Fe-Zn-O system : application to the dust formation in EAF. In : Proceedings of the $10^{\text {th }}$ International IUPAC Confrence on High Temperature Materials Chemistry, Hilert, K. (Ed.), Julich, Germany, 10-14 April 2000, pp. 1-12.

Sidenor S.A. Iron Process Industry - Thessaloniki, Greece (2008), Information from personal communication of corresponding author with staff members of the company.

Sikalidis, A., Fitch, M.D., Fleming, S.E. (2006), Obesity and the risk of colon cancer in mouse models, Faseb Journal, 20, 5, A-1013

Sikalidis C., Mitrakas M. (2006), Utilization of electric arc furnace dust as raw material for the production of ceramic and concrete building products, J. Environmental Science and Health, Part A. 41, 1943-1954.

Sofilić T., Rastovčan-Mioč A., Cerjan-Stevanović Š., Novosel-Radović V., Jenko M.(2004), Characterization of steel mill electric-arc furnace dust, J. Hazardous Materials, B109, 58-70.

Apha, AWWA, WEF (1992) Standard Methods for the examination of water and wastewater (1992), Apha, AWWA, WEF, $18^{\text {th }}$ edition.

Valavanidis A., Fiotakis K., Vlachogianni T. (2008), Airborn particulate matter and human health: Toxicological assessment and importance of size and composition of particles for oxidative damage and carcinogenic mechanisms, Journal of environmental science and health, part C - Environmental carcinogenesis and ecotoxicology reviews, 26(4), 339-362.

Yang J., Mosby D., Casteel S., Blanchar R. (2001), Lead immobilization using phosphoric acid in a smelter contaminated urban soil, Environ. Sci. Technol., 35, 3553-3559.

Zunkel A.D., Schmitt R.I. (1995), Review of EAFD treatment processes and environmental regulations. Electric Arc Furnace Conference Proceedings, CMT, Pittsburg, 147-158. 